\title{
IAMJ
}

INTERNATIONAL

AYURVEDIC

MEDICAL JOURNAL

ISSN: 23205091

Impact Factor: 5.344

\section{CHRONIC ECZEMA MANAGED WITH AYURVEDIC TREATMENT - A CASE STUDY}

\author{
Thakor Narendrasinh $\mathbf{M}^{1}$, Gamit Anupriya $\mathbf{R}^{2}$ \\ ${ }^{1}$ Consultant, Department of Shalya, Vasant Prabha Ayurvedic Hospital, Vadnagar, Gujarat, India \\ ${ }^{2}$ Consultant, Department of Panchakarma, Vasant Prabha Ayurvedic Hospital, Vadnagar, Gujarat, India
}

Corresponding Author: mgthakor14@gmail.com

https://doi.org/10.46607/iamj12p4052020

(Published online: July 2020)

Open Access

(C) International Ayurvedic Medical Journal, India 2020

Article Received: 04/06/2020 - Peer Reviewed: 25/07/2020 - Accepted for Publication: 31/07/2020

Check for updates

\section{ABSTRACT}

Background: Atopic dermatitis, also known as atopic eczema, is a chronic inflammatory skin condition characterized by pruritic, erythematous, and scaly skin lesions often localized to the flexural surfaces of the body. A genetic defect in the filaggrin protein is thought to cause atopic dermatitis by disrupting the epidermis. This disruption, in turn, results in contact between immune cells in the dermis and antigens from the external environment leading to intense itching, scratching, and inflammation. Scratching can then lead to further disruption and inflammation of the epidermal skin barrier; this has been described as the itch scratch cycle. According to Ayurve$d a$, it is Raktapradoshajavikara, in which Tridosha are involved, with dominance of Kapha. The management available in current mainstream medicine is unsatisfactory; Various Ayurvedic treatments have been in use for these manifestations.

Case Presentation: A 55 years old female patient presented with complaints of itching in both legs, sometimes in elbows, patches in both legs since 4 years. She has also known case of HTN since 10 years.

Management \& Outcome: Patient was admitted in Vasant Prabha Ayurvedic Hospital and was put on Ayurvedic treatment that consisted of whole body Abhyanga, Bashpaswedana, rectal drug administration (Niruhbasti) and other medicaments. She stayed for 30 days in the hospital. This case highlights the importance of Ayurvedic treatment in providing fast improvement in skin disease. What benefits the lady could not get in last four years have been achieved by her in just 30 days. 
Keywords: Chronic eczema, Abhyang, Virechana Rectal drug administration (Niruhbasti), Raktamokshana.

\section{INTRODUCTION}

Eczema is considered to be one of the most common skin diseases. Topical corticosteroids are the most widely prescribed medication for dermatological diseases including eczema as they are so efficient in treating inflammatory and epidermal proliferative diseases. Occasionally, it will be necessary for patients with extensive disease to be treated with large quantities of the more potent preparations for a short time. However, with large quantities of these potent preparations transient adrenal suppression is likely to occur, especially early in the treatment. Also, evidence of mild suppression of the HPA axis - 'hypothalamic pituitary adrenal axis' is reported in adults when the more potent topical steroids were used, with rapid recovery of the function when intensive treatment ceased. Untreated or partially treated eczema becomes more chronic requiring treatment for a longer period. There is possibility of increase in the cutaneous flora of micro-organisms and dermatophytes, during the treatment with a steroid preparation. The cost becomes prohibitive and quantity inadequate as corticosteroid preparations is not economical particular for poor patients of eczema where it is more common ${ }^{1}$. Description of a skin disease similar to that of eczema is in Ayurvedic classical text as Vicharchika, viz, "Sakandu Pidaka ShyavaBahusrava" meaning skin lesion with hyper pigmentation, vesicles, itching and profuse exudation is termed Vicharchika. As it is Raktapra- doshajvikar, the mainstay of treatment in Ayurveda for Vicharchika is Shodhana, which eliminate the vitiated Doshas. Parallel to Shodhana, Shamanoushadis help to correct the Dhatus and bring them to normal$\mathrm{cy}^{2}$.

Case Presentation: A 55-year-old lady came to OPD of Vasant Prabha ayurvedic Hospital, Vadnagar; Gujarat, India for Ayurvedic treatment. She had the following chief complaints.

1.B/L itchy patches in leg since 4 years; 2 . Itchiness increases in night; 3. Constipation; 4. Burning

History of Present Illness: Patient was relatively healthy before 10 years, she diagnosed with HTN before 10 years, and before 4 years she developed complaints of itching in whole body, mostly in both legs and hands. Gradually she developed patches in both legs; also, she started having complaint of constipation. She had taken allopathic

Treatment, but didn't get satisfactory relief, so she came here for further treatment on 1/1/2020. Family history: Negative for HTN, DM or any skin diseases.

\section{Pathological Investigation}

2/1/2020Hb: $12.3 \mathrm{mg} / \mathrm{Dl}$

\section{Clinical Examination}

CVS: 82/min, RRR, normal S1 S2 sound, no murmur RS: B/L air entry normal with clear breath sounds Mental status: depressed

Table1: Gradation of symptoms / subjective parameters of eczema

\begin{tabular}{|l|l|l|}
\hline Symptoms & Gradation & Score \\
\hline \multirow{3}{*}{ Kandu (Itching) } & No itching & 0 \\
& Itching present rarely & 1 \\
& Itching disturbing patient's attention & 2 \\
& Severe itching disturbing patient's sleep & 3 \\
\hline \multirow{3}{*}{ Shyavta (Discoloration) } & Normal skin colour & 0 \\
& Brownish red discoloration & 1 \\
& Blackish red discoloration & 2 \\
& Blackish discoloration & 3 \\
\hline \multirow{3}{*}{ Daha (Burning sensation) } & Absence of burning sensation in affected part & 0 \\
& Rarely burning sensation in affected part & 1 \\
& Continues burning sensation in affected part & 2 \\
& Disturbing patient's sleep & 3 \\
\hline
\end{tabular}




\section{Treatment \& Outcome}

Table 2: Line of treatment

\begin{tabular}{|c|c|}
\hline Day & Treatment \\
\hline $1-3$ & $\begin{array}{l}\text { Sarvangabhyang (Jatyaditaila) } \\
\text { Sarvangbashpasvedana (Nimbpatra) }\end{array}$ \\
\hline $4^{\text {th }}-5^{\text {th }}$ & Samsarjan karma \\
\hline $6^{\text {th }}-12^{\text {th }}$ day & $\begin{array}{l}\text { Nimbghanvati }(250 \mathrm{mg}) 2 \mathrm{tab} 2 \text { times } \\
\text { Gandhakrasayan }(250 \mathrm{mg}) 2 \mathrm{tab} 2 \text { times } \\
\text { Kaishorguggulu }(250 \mathrm{mg}) 2 \mathrm{tab} 2 \text { times } \\
\text { Manjisthadikwath } 40 \mathrm{ml} 2 \text { times } \\
\text { Gandhak }+ \text { Jatyadimalam for local application } \\
\text { Panchtiktaghritashamanarthsnehpana } 20 \mathrm{ml} 2 \text { times }\end{array}$ \\
\hline $13^{\text {th }}$ day & Raktamokshan - Sira vedh \\
\hline $14^{\text {th }}-30^{\text {th }}$ day & Medicines and Shamanarthasnehpan \\
\hline $2^{\text {nd }}$ follow up & $\begin{array}{l}\text { Gandhakrasayan }(250 \mathrm{mg}) 2 \text { tab } 3 \text { times } \\
\text { Kaishorguggulu }(250 \mathrm{mg}) 3 \text { tab } 3 \text { times } \\
\text { Nimbghanvati }(250 \mathrm{mg}) 2 \text { tab } 3 \text { times } \\
\text { Manjisthadikwath } 40 \mathrm{ml} 2 \text { times } \\
\text { Gandhak }+ \text { Jatyadimalam for local application } \\
\text { Gandharvaharitaki tablet }(250 \mathrm{mg}) 5 \text { tablets HS }\end{array}$ \\
\hline
\end{tabular}

Table 3: Showing changes in symptoms before and after treatment

\begin{tabular}{|l|l|l|}
\hline Symptoms & Grade before treatment & Grade after treatment \\
\hline Kandu & 4 & 0 \\
\hline Shyavata & 3 & 1 \\
\hline Daha & 1 & 0 \\
\hline
\end{tabular}

Results: The patient had started improving during treatment and at the end of $28^{\text {th }}$ day there was overall recovery, with Ayurvedic treatment she has relief in all the Subjective and Objective parameters.

Classification of Vicharchika: The Charaka Samhita and Sushruta Samhita classify skin diseases into two categories.

The Mahakushtha (Major) and Kshudrakushta (Minor) $)^{3,4,5}$

Mode of action of Virechanakarma in Vicharchika: Virechana (systemic purification by giving purgative drug) is better for the skin diseases where Pitta and Rakta are mainly involved. Due to Koshthashuddhi medicine's effect increases. Also, it decreases reoccurrence of disease ${ }^{6}$.

Mode of Action of Gandhak rasayan in Vicharchika: Gandhak rasayan Vati is effective in treatment of Vicharchika. Different Bhavana dravyas in Gandhak rasayan act as bactericidal and thus causes blood purification. Bhavanadravyas like Guduchi, Nagkeshar, Haritaki, Sunthi, has properties of Katu, Kashay Rasa and Ushna Virya. Thus, it does Dipana, Pachana, Kledhar and Kaphghna and in this way also acts as Kushtaghna and Kandughna, which helps in curing the disease ${ }^{7}$. 


\section{Mode of action of Raktamokshan in Vicharchika:} Symptoms like Twakvaivarnta, Kandu, Daha will reduce after Siravedha Karma due to Prabhutdosha Nirharan by Siravedha and Raktashudhhi, Sharirlaghvta, Vedana shanti, Twakshotha. According to Charak and Sushruta, Shodhan is necessary for disease due to the Bahudosha Avastha. As Vicharchika (eczema) is Vata- Kaphaj Condition, so Siravedha karma (Bloodletting) can be given in Vicharchika. Although Vicharchika (eczema) is considered as a disease of Bahyaroga Marg, the initiation of pathogenesis is from the Koshtha. However, applying the usual Shaman principles of treatment of Vicharchika according to Nidan and Samprapti, will inevitably result in only partial cure, therefore Sanshodhan Kar$m a$ is considered as the best line of effective treatment. Siravedha (bloodletting) procedure is effective to absorb toxic materials so they can be easily evacuated from body. Beside eliminating Pitta and Kapha Doshas, the main seat of Vata is also purified thereby making Siravedha Karma a truly Tridoshahar procedure $^{8}$

Mode of action of Nimbghanvati in Vicharchika: Nimb due to its Tikta Guna, does Raktasuddhi. Its Laghu and Ruksha Guna are effective as it is a Santarpanotthavyadhi described in Charaksamhita, Sutrasthan. Also, its Sheet potency pacifies Pitta. Charak described it in Kandughnavarga. It is also indicated in Kushtha.

\section{Mode of action of Kaishor Guggulu:}

In Sharandhar samhita madhyam khand-7, verse "Jayet Sarvani Kushthani" is mentioned about Kaishor Guggulu. Main drug used in Kaishor guggulu is Triphala, which is described in classics in Kushtha Chikitsa.

Mode of action of Manjishthadikwath: Manjishthadikwath has contents like Manjishtha, Guduchi,
Bakuchi, Nimb, Haridra, Patola etc., which not only detoxifies but purifies blood. Also helps in pacifying KaphaDosha. Kushtha is a Santarpanottha Vyadhi as per Charak Samhita. Manjishthadikwath also helps to reduce obesity.

\section{Mode of action of Panchtikta Ghrita:}

It is described in Bhaisajya Ratnavali Kushtharogadhikar 114-11, Shaman sneh pan indications are described in Charak Samhita Sutra sthan.

\section{DISCUSSION}

Causative factors of Eczema or Vicharchika are faulty diet and lifestyle, which leads to impairment of digestion and aggravation of Kapha Dosha ${ }^{9}$. Kapha manifests in the skin and causes accumulation of toxins. The vitiated three Doshas- Vata, Pitta, Kapha along with impaired Tvak, Rakta, Mamsa and Ambu together constitute seven essential entities which play role in pathogenesis of this skin disorder and Kapha is the predominant Dosha involved in Vicharchika ${ }^{10,11}$. Recurrent skin rashes over extensor surface of leg characterized by redness; itching and cracking were the symptoms of patient. KaphaDosha is responsible for symptoms like pruritus, non-progressive / slow progression of it. Patient was asked to avoid food, which is heavy to digest, sour food, milk and curd.

\section{CONCLUSION}

Vicharchika comes under Kshudrakustha described in various classics. It has Kapha dominancy and also Tridosha involvement can be evident from sign and symptoms. It is skin disease, it looks hideous, and so patient has not only physical but also sometimes mental symptoms. All the medicines used are most of Tikta Rasa, which purifies Rakta, pacifies Pitta. Also, local application of Gandhak and Jatyadimalam acts on Bharajak Pitta. 
Image 1: Before treatment on $1^{\text {st }}$ day

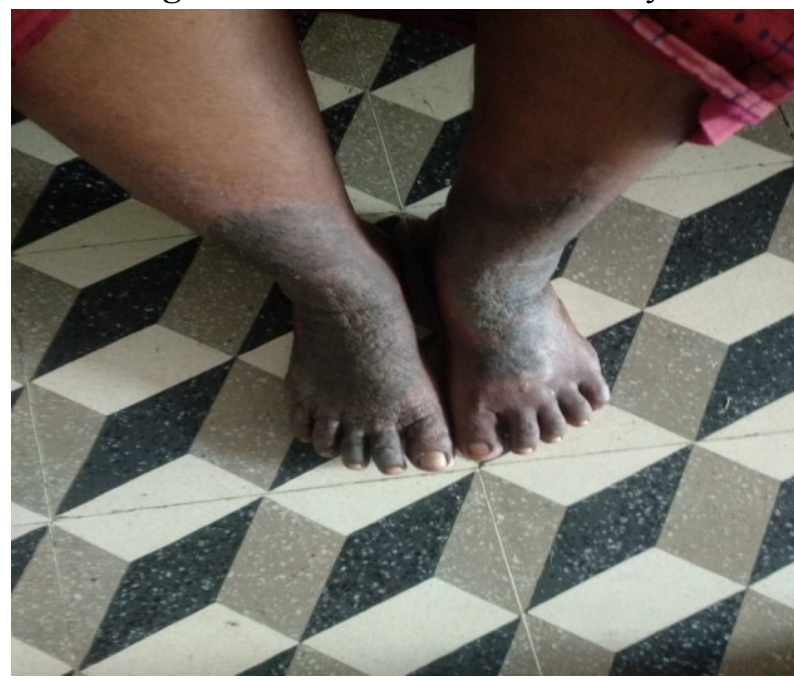

Image 2: After treatment on $28^{\text {th }}$ day

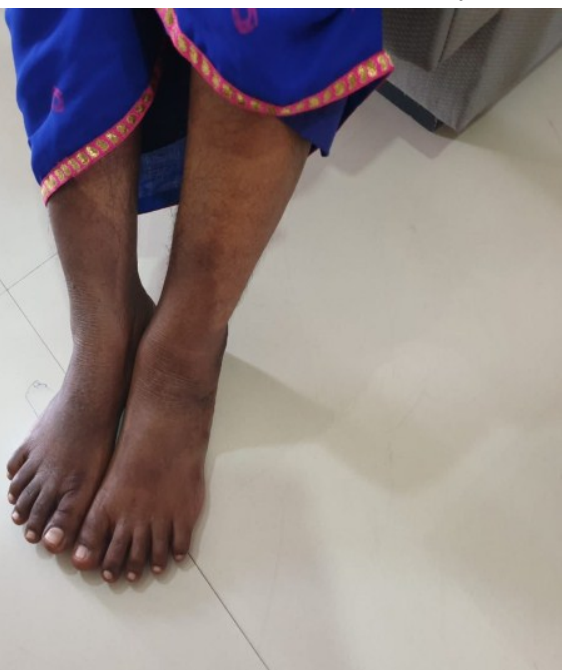

\section{REFERENCES}

1. The NHS Website:nhs.uk, Available from: https://www.nhs.uk/conditions/atopic-eczema/

2. Hegde P, D T Hemanth, S V Emmi, M P Shilpa, Shindhe S,YM Santosh, A Case discussion on eczema,2010,OCT-

DEChttps://www.ncbi.nlm.nih.gov/pmc/articles/PMC3 059451/DOI: https://dx.doi.org/10.4103\%2F09747788.76792

3. Agnivesh, Charaksamhitachikitsasthan Hindi Commentary By Panditkashinathshastri Chaukhambha Publication, Varanasi Reprint 2011:7/13 Page 250.

4. Sushrutsamhita Nidansthan Ambikadattsahastri, Chaukhambha Publication, Varanasi Reprint 2012;5 Page 320 .

5. Vagbhatta, Ashtanghridaya With Sarvangasundari Commentary of Arunadatta \&Ayurvedarasayana of Hemadri, Edited By Pt. Hari Sadashiva Shashtri, Chaukhambha Surbharati Prakashan, Varanasi, Reprint 2007; Nidana Sthana, Pg.525.

6. Astangsangrahuttarsthan (39\62) Sarwangsundarivakhaya, Lalchandvaidh, Chaukhambha Publication, Varansi.

7. Kaur M, Chandola H, Role Of Virechana Karma In Cure And Prevention Of Recurrence Of Vicharchika (Eczema), Oct 2012, Medknow Publications \& Media Pvt Ltd. Available From: https://www.ncbi.nlm.nih.gov/pmc/articles/PMC36651 94/
8. Brahma Shankar Shashtri, Laxmipatishashtri, Vidhyotinihinditika, Yogratnakar, Rasayanadhikar, Chaukhambha Publication;2011, Varanasi.

9. Bhavprakashnighantu $28^{\text {th }}$ Edition Of 2010, Verse 1316, P. 31

10. Agnivesha, Charaka, Dridhabala. Charaka Samhita, Chikitsasthana, Kushthachikitsa Adhyaya, 7/30. In: Jadavaji Trikamji Acharya., Editor. 5th Ed. Varanasi: Chaukhambha Sanskrit Sansthana; 2001. P. 185.

11. Agnivesha, Charaka, Dridhabala. Charaka Samhita, Chikitsasthana, Kushthachikitsa Adhyaya, 7/10. In: Jadavaji Trikamji Acharya., Editor. 5th Ed. Varanasi: Chaukhambha Sanskrit Sansthana; 2001. P. 182.

\section{Source of Support: Nil Conflict of Interest: None Declared}

How to cite this URL: Thakor Narendrasinh M \& Gamit Anupriya R: Chronic Eczema Managed With Ayurvedic Treatment- A Case Study. International Ayurvedic Medical Journal \{online\} 2020 \{cited July, 2020\} Available from: http://www.iamj.in/posts/images/upload/2437_2441.pdf 